\title{
PSYCHE.
}

\section{NOTES ON OUR SPECIES OF EMESIDE.}

\author{
BY NATHAN BANKS.
}

THE insects of the Hemipterous family Emesidæ, commonly known as "skeletonbugs," are not often taken by the collector. A number of species are, however, quite abundant, when one knows where to look for them. They are usually adult in the late summer and fall, and most are found in November and December, under boards, at the base of tufts of grass, or on the ground. A few are more common on tree-trunks, or dead logs.

During the past few years I have accumulated quite a number of these forms, including all those recorded from the United States, and a number of new forms. Twelve species are here recorded, and as many more will undoubtedly be found, as our country is more thoroughly explored.

\section{Table of Genera.}

1. Trochanter I bearing two small but distinct spines; tibia I not half as long as

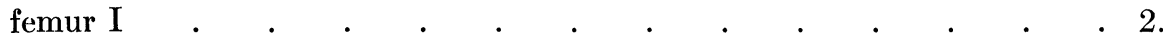
Trochanter I without spines $\quad . \quad$. $\quad . \quad$. $\quad . \quad . \quad . \quad . \quad . \quad 3$.

2. Body winged; antennæ hairy . . . . . . Ploiariopsis. Body apterous; antennæ not hairy . . . . . . Ploiaria.

3. Tibia I nearly as long as femur I . . . . . . . . . . 5. Tibia I hardly one-half as long as femur I . . . . . . . . . 4.

4. Tylus between antennæ is very prominent; prothorax well separated from mesothorax; head fully one-half as long as coxa I . . . . Barce. Tylus between antennæ not prominent; prothorax not so distinctly separated from mesothorax; head less than one-half as long as coxa I . . . Emesa.

5. Prothorax shorter than the head, and united to the mesothorax Ploiariodes. Prothorax longer than head, and distinct from the mesothorax . . Luteva. 


\section{Ploiariopsis.}

Champion, Biol. C. Am. Rhynch. Het. II, 173, 1898.

\section{Ploiariopsis hirticornis $\mathrm{n} . \mathrm{sp}$.}

Brown, head pale above, basal joint of antennæ dark brown beneath, rest pale, second and third joints very long and with many long fine hairs; beak with three black bands; coxa I dark brown, femur I streaked beneath with dark brown and a preapical band; tibia dark, spines pale, other legs pale, abdomen dark brown, wings pale, all veins margined with brown, giving a reticulate appearance to the wings. Head with an acute median spine behind, trochanter with a prominent double spine, femur with spines throughout its length, these of two sizes, many small ones and about five larger ones, which are as long as the width of the joint; prothorax subequal to the mesothorax; wings reaching beyond the end of the abdomen; the latter is very slender, and ends in a pair of short processes curved toward each other.

Length $7 \mathrm{~mm}$.

From Southern Pines, N. Car., Dec. (Manee).

\section{Ploiaria.}

Scopoli, Flor. Faun. Insubr. I, 60, 1786.

We have two species of this genus, one is the Emesodema carolina of HerrichSchaeffer, which has been placed by some in Luteva, but wrongly.

1. With five long spines on femur I . . . . . . . P. carolina.

With six long spines on femur I . . . . . . . $\quad$. P. texana.

Ploiaria texana n. sp.

A specimen from College Station, Texas, Sept., is in general very similar to the described species, $P$. carolina, but is a little larger. It differs in having six long spines on femur I (five in P. carolina), and in lacking the tubercle, and median spine to the posterior part of head; the prothorax is longer, nearly twice as long as head, and also coxa $\mathrm{I}$ is longer than in $P$. carolina.

Ploiaria carolina Her.-Schf.

Wanz. Ins. IX, 115, 1853.

Mr. Manee has sent me this species from Southern Pines, N. Car., Dec., and I also have it from Shreveport, La. It has a double spine on trochanter I, the beak 
banded, the femur I black beneath, with five long spines and many small ones; there is a median spine behind on the head, and a short one at each anterior corner of the posterior part of head; the antennæ are without hairs; the legs show a dark preapical band on femora, and a sub-basal one on tibiæ. The abdomen is nearly black, and there is no trace of wings; the upper edge of the last segment of the male has three little conical tubercles in a transverse row, and the tip has a short cylindrical tube; a female, with swollen abdomen, has a median tubercle in the middle of each dorsal segment, that on the third segment being the largest. Length $7 \mathrm{~mm}$.

\section{Luteva.}

Dohrn, Linn. Ent. XIV, 213, 1860.

\section{Luteva arizonensis $\mathrm{n}$. sp.}

Pale brownish; antennæ brown, second joint with four narrow yellowish wings, two on the third joint, both joints with short hairs. Femur I mostly brown, apex pale, tibia I with pale band at base and before the middle; frontal slope of mesonotum pale, rest dark brown; abdomen pale brown, legs brown, femora with five pale bands and the apex pale; tibiæ with three pale bands; wings brownish, the costal margin yellowish. Coxa I much longer than prothorax, femur with many short and very fine spines, tibia about as long as femur, and the tarsus reaching over the trochanter; eyes prominent; prothorax constricted behind, in front with a tubercle at each corner; scutellum with a long erect spine at base, and a shorter one at apex; wings extending over the tip of the abdomen.

Length $10 \mathrm{~mm}$.

From Palmerlee, Arizona, August (Biederman).

\section{Ploiariodes.}

White, Ann. Mag. Nat. Hist. (5) VII, 58, 1881.

Our described species has been placed in Cerascopus, which is a synonym of Ploiaria. Champion has shown their proper position.

1. Mesonotum behind with a prominent median tubercle . P. tuberculata.

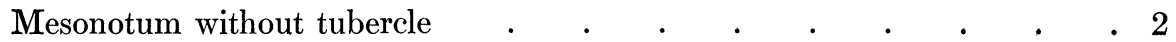

2. Spine at base of scutellum longer than one at apex; Eastern species.

P. errabunda.

Spine at base of scutellum shorter than one at apex; Western species.

$P$. californica. 
Ploiariodes errabunda Say.

Hem. N. Harm. 34, 1832.

maculata Hald., Proc. Acad. Phil. III, 151, 1847 (Ploiaria).

I have this species from Falls Church, Va., and Plummer's Island, Md., in July, August, and September. It has usually been taken on logs of wood, but once I found two specimens on the bark of a live tulip tree, and one was taken at light. There is some variation in the depth of coloration, enough to easily cover Haldeman's form.

\section{Ploiariodes tuberculata $\mathrm{n}$. sp.}

Brown, the pronotum blackish, the legs and antennæ pale, annulate with black on the basal parts, the wings brown or blackish, reticulate with whitish. In general it is similar to P. errabunda, but the wings are more evenly marked, the femur I is rather longer, and it is a slightly larger insect, but the most prominent difference is the black conical tubercle near the posterior border of the mesothorax; the posterior lateral corners of the mesothorax are also more prominent than in P. errabunda.

Length $5.2 \mathrm{~mm}$.

From Sea Cliff, N. Y., and Falls Church, Va., in August and September. Ploiariodes californica $\mathrm{n}$. sp.

Pale brown, mesonotum with two whitish stripes, pronotum with a black line each side; legs and antennæ banded. Wings mottled as in the other species, more heavily and evenly brown than in P. errabunda; the middle band on tibia I is broader than in P. errabunda. It differs also from P. errabunda in that the spine at the base of the scutellum is shorter than the one at its apex.

Length $5 \mathrm{~mm}$.

From Stanford Univ., Calif. Sept. (Doane).

\section{BARCE.}

Stål, Hem. Afric. III, 163, 1865.

Three species are fairly common in the Eastern U. S., one specimen of another species I have from Texas, and doubtless others will be found in the West.

1. Femora II and III with several bands; median carina of mesothorax not distinct. B. annulipes.

Femora unbanded, or only one near apex, median carina of mesothorax distinct. 
2. Femora II and III with a dark preapical band, and a white ring on basal part of tibia, femur I mottled with brown and pale in streaks . . B. fraterna. Femora II and III, and these tibiæ without bands; femur I unmarked, pale brown to black . . . . . . . . . . B. uhleri.

Barce uhleri n. sp.

Brown to black, mostly unmarked, some pale spots at edge of each segment of the female abdomen, and a few pale spots on femur and tibia I; legs uniform pale brown. The armature of femur I is similar to that of the other species; the long spine is nearly twice the diameter of the joint at this point; coxa $\mathrm{I}$ is about as long as the prothorax. The mesonotum shows three carinæ, and less distinctly one each side. The tip of the female abdomen is barely emarginate; one male has brown wings covering two-thirds of the abdomen. Length
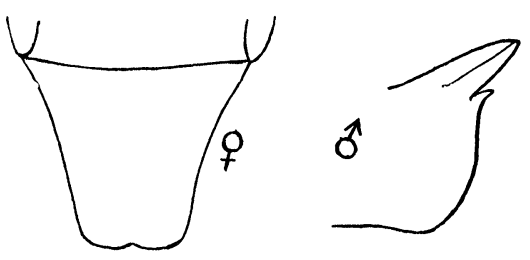

Fig. 1. - Barce uhleri, last abdominal segment, of male and female. $10 \mathrm{~mm}$.

From Southern Pines, N. Car., Dec. (Manee).

These specimens are black, with only faint traces of pale spots. Other specimens from Sea Cliff, N. Y., and Falls Church, Va., are paler brown, the spots on abdomen distinct, and the femur I rather stouter in the middle, and the prothorax is shorter; but the tip of the abdomen is the same. These may be called Barce uhleri var. brunnea; their length is $8.5 \mathrm{~mm}$.

Barce annulipes, Stål.

Berl. Ent. Zeits. 1866, 168.

This species is very distinct by the several dark bands on the femora; femur I shows several dark spots beneath. Young specimens have the legs even more distinctly banded than the adults. I have never seen a winged specimen. Specimens are before me from Sea Cliff, and Ithaca, N. Y., from Falls Church, Va., and from Shreveport, La. It is usually taken in dry meadows.

\section{Barce fraterna Say.}

Hem. N. Harm. 33, 1831.

This is our largest species of the genus. The immature specimens do not usually show the dark preapical band to the femora, but the fully colored ones have it 
distinct. About one in every six or eight taken is winged; the wings covering all but the last three segments of the abdomen. I have taken it commonly at Falls
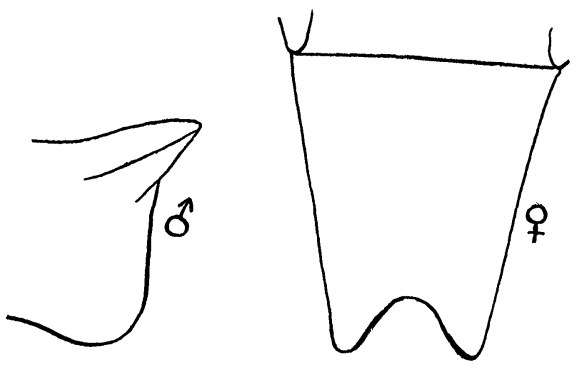

Fig. 2. - Barce fraterna, last abdominal segment of male and female.

if at all, visible in the other species. Church at the base of tufts of grass in moist fields, in Oct. and Nov. I have it also from Chesapeake Beach, Md., Cambridge, Mass. (Sept., in a marsh), and Southern Pines, N. Car., Nov. and Dec. (Manee). The Emesodema simplicipes Uhler, must be the immature stage of $B$. fraterna, for he says that the femur $I$ is clouded with brown, nearly white beneath, which fits this species and not the B. uhleri; moreover, he says the long spine is tipped with black, which is prominent in B. fraterna, and barely,

\section{Emesa.}

Fabr., Syst. Rhyng. 263, 1803.

To this genus belong the largest members of the family. They are winged when adult, and there is but one generation a year. We have two species, and possibly others.

Emesa longrpes De Geer.

De Geer, Mém. Ins. III, 352, 1773.

brevipennis Say, Amer. Ent. III, pl. 47, 1828.

This species is common in the Eastern United States; it occurs on trees, on unpainted buildings, on spider webs, etc. It flies at twilight.

Emesa brevicoxa n. sp.

This species is similar to $E$. longipes, but coxa $\mathrm{I}$ is a third shorter than in that species, hardly twice as long as the head (while in E. longipes it is over twice as long as the head); the femur I is also shorter; the tip of the female abdomen has not the two processes as strong as in E. longipes. The legs are marked the same, and the wings are of the same length. The whole insect is a little shorter than $E$. longipes. From Los Angeles, Calif. (Hutchinson). 

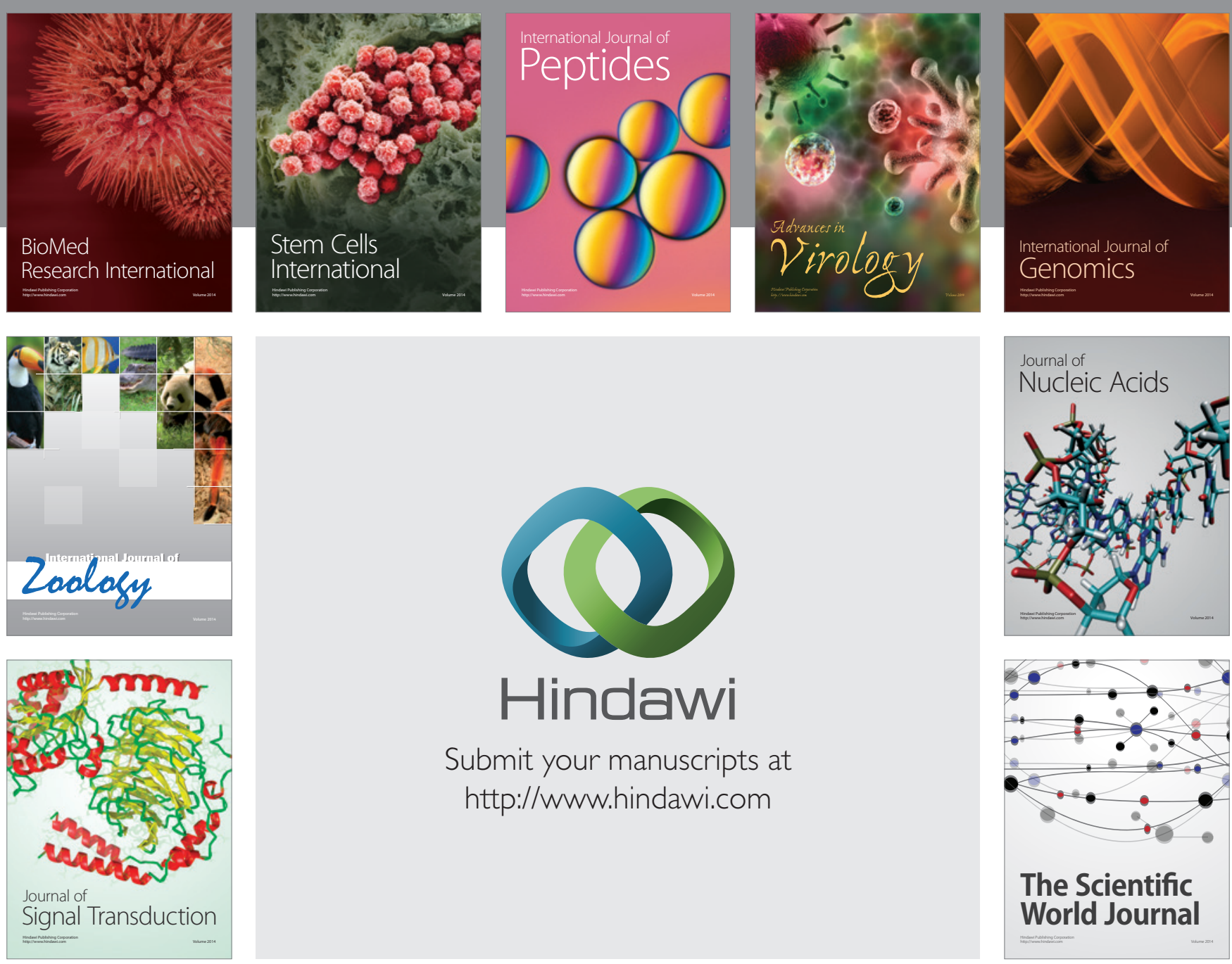

Submit your manuscripts at

http://www.hindawi.com
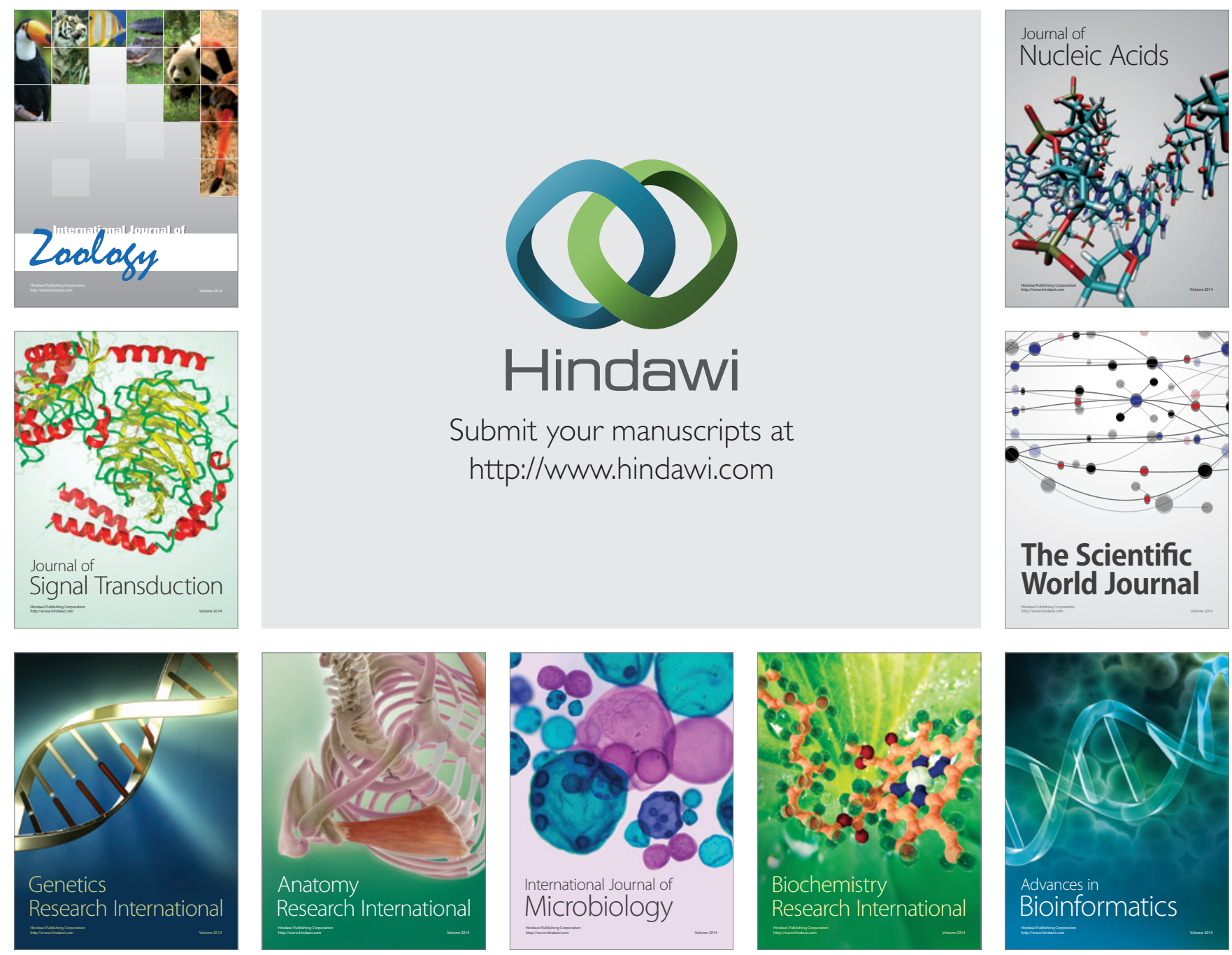

The Scientific World Journal
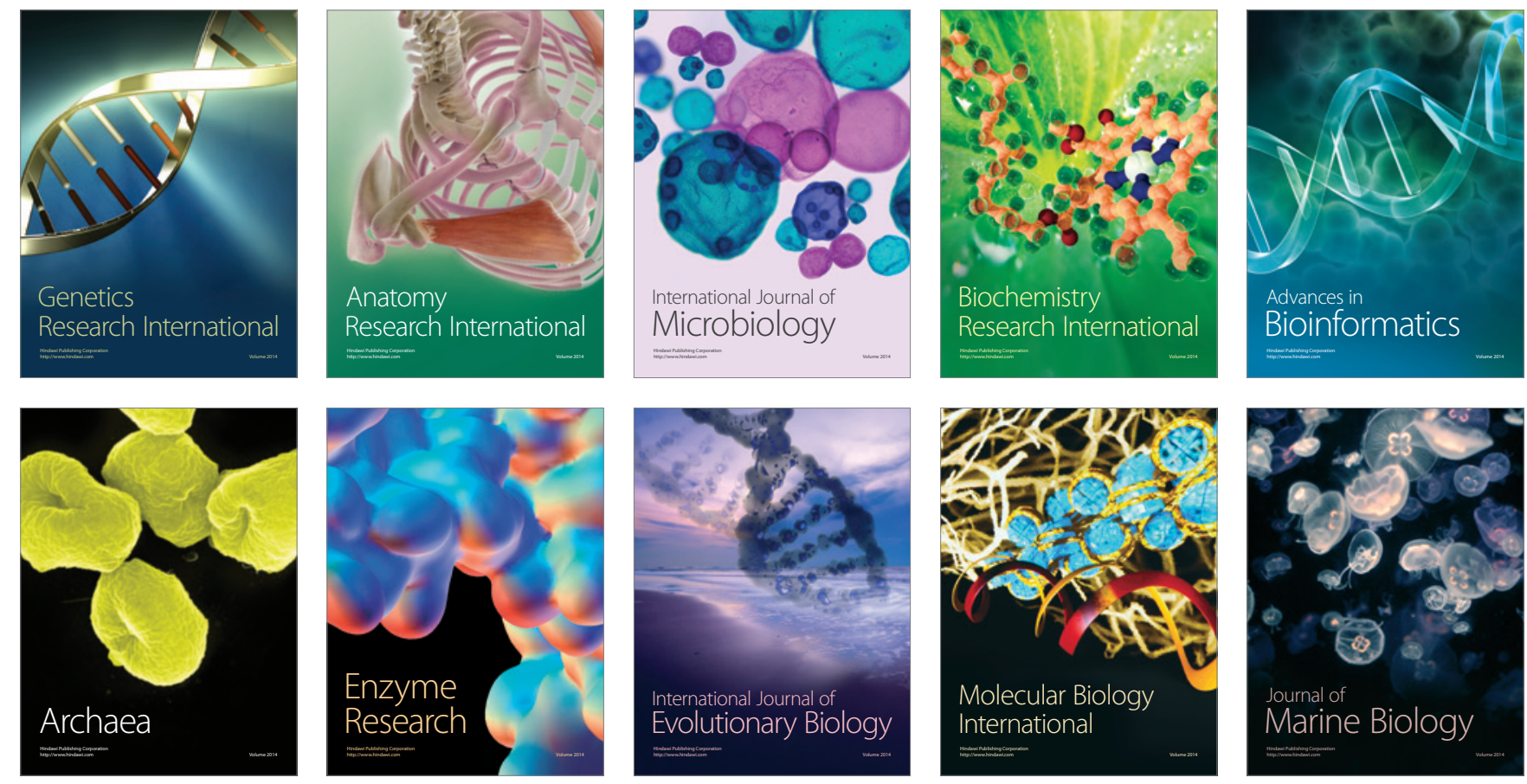